\title{
Understanding the Role of Stakeholder in the Formation of Tourist Friendly Destination Concept
}

\author{
Ahmad Nazrin Aris Anuar ${ }^{1}$, Habibah Ahmad², Hamzah Jusoh² \& Mohd Yusof Hussain² \\ ${ }^{1}$ Centre of Studies Park \& Amenity Management, Faculty of Architecture, Planning \& Surveying, Universiti \\ Teknologi MARA, Shah Alam, Malaysia \\ ${ }^{2}$ School of Social, Development and Environment, Faculty of Social Sciences and Humanities, National \\ University of Malaysia, Bangi, Malaysia \\ Correspondence: Ahmad Nazrin Aris Anuar, PhD Student, School of Social, Development and Environment, \\ Faculty of Social Sciences and Humanities, National University of Malaysia, 43600 UKM Bangi, Selangor Darul \\ Ehsan, Malaysia. Tel: 60-13-364-6137. E-mail: aek_2751@yahoo.com
}

Received: April 1, 2012 Accepted: April 25, 2012 Online Published: May 24, 2012

doi:10.5539/jms.v2n2p69 URL: http://dx.doi.org/10.5539/jms.v2n2p69

The research is financed by Ministry of Higher Education Malaysia, Universiti Teknologi MARA and National University of Malaysia.

\begin{abstract}
The tourist friendly destination is a concept that provides satisfaction to tourists through maximum utilisation of the aspects of space, activities and products sans interference or problems, beginning from a tourist's place of origin all the way to the desired tourism destination. It is viewed as a concept that prioritises tourists as customers. However, studies that of such initiatives are quite limited and sector based, thus leaving a gap of knowledge and misunderstanding about a usage of tourist friendly destination. In light of this predicament, this study is a concept paper with the aims of identifying stakeholder and their roles in the formation of tourist friendly destination concept. Through this study, it is found that the formation of tourist friendly destination concept were responsible by public sector and private sector together with domestic tourist through the aspects of space, activity and product in tourism system approached. Therefore, this study will attempt to shape this concept through cooperation from stakeholder as part to follow the demand and need of tourist as customer in tourism destination.
\end{abstract}

Keywords: customer oriented branding, stakeholder, tourism system, tourist friendly destination

\section{Introduction}

Tourist friendly destination is a concept that provides satisfaction by fulfilling tourists' wants and needs through the maximisation aspects of space, activity and products sans interference or problems, beginning from a tourist's place of origin all the way to the desired tourism destination (Anuar, Ahmad, Jusoh \& Hussain, 2012). What is interesting about such a concept is the facilities they offer not only to tourists, but also to local residents through holiday packages which include reasonable prices, distribution rates, development and use of infrastructure, facilities, accommodation, transport, internet usage, marketing methods and easy ways to disseminate marketing. Although research in tourist friendly destination concept is limited due to a lack of existing literature especially theories, concepts, frameworks and indicators, preliminary studies such as this one are necessary as an introduction to the basic concept of tourist friendly destination. Therefore, within the tourism system approach, a tourist friendly destination concept is created through a combination of the aspects of space, activity and product (Anuar et al., 2012). Each aspect plays its own role with the ultimate aim of making tourists feel at ease and free from any worries. According to Swarbrooke (1995), tourists have a tendency to respond to a friendly destination where the facilities and services are easily accessible; time can save entirely without any interruption starts from residence until they choose of tourism destination.

However, the role of relevant parties, specifically stakeholder is also crucial. Yet who exactly constitutes stakeholder? Savage, Nix, Whitehead and Blair (1991) defines stakeholders as individuals or groups with an interest in actions and have great influence. According to Carroll (1993), stakeholders are individuals or groups that may influence or be influenced by the actions, decisions, policies, practices or goals of an organisation. 
However, both of these points are only general definitions whereas in terms of tourism destinations, especially in tourist friendly destination its meaning may differ. Therefore, the objective of this study is to identifying stakeholder (especially public \& private sector and domestic tourist) and their roles in formation of tourist friendly destination concept.

\section{The Role of Stakeholder in the Formation of Tourist Friendly Destination Concept}

Stakeholders in tourism destination may refer to tourists (as the demand), industries (as the supplier) and hosts (the local community and environment) (Pavlovich, 2003). They may also refer to sectors i.e., business sectors, non-profit sectors and public sectors (Gunn, 1994). According to the World Tourism Organisation (WTO), stakeholders in sustainable tourism development are divided into three categories: the tourism industry, environmental support and the local community/government (Timur, 2012). WTO also outlines the tourism industry's role to create opportunities for business, employment, income and foreign currency exchange through the provision of tourism services (including transportation, accommodation, food and beverages). Meanwhile, the environment's role is to attract tourists to participate in activities based on local culture, nature, architecture (man-made). Finally, the local community/government (which includes residents and local businesses, organisations and associations) functions to make decisions (Timur, 2012). This shows that all three stakeholders have their respective roles in shaping sustainable tourism. In this respect, stakeholders can also be used to create tourist friendly destination where elements within the sustainable tourism development model constitute subsectors that encompass preparations in relation aspects of space, activities and products.

However, a different approach is employed when it comes to determining the identity and roles of stakeholders in urban tourism. According to Timur (2001), stakeholders in urban tourism consist of the industry and government (at the municipal, regional or national level) only. Both parties act to uphold physical heritages in towns, strengthen the culture and social viability of local residents and provide long-term development and work opportunities (Paskaleva-Shapira, 2001). These tasks are indicative of the use of space, activities and products that stakeholders are required to provide to tourists.

In a study by Ritchie and Crouch (2003), stakeholders in tourism destinations are classified as suppliers and supporting industries, marketing intermediaries and facilitators, members of the public and local as well as foreign customers. Suppliers function to provide all the required elements based on tourists' needs. In accordance with this, the suppliers will fulfil the aspects of space, activities and products in tourism destinations to fulfill the tourists' satisfaction and experiences. During this process, suppliers must always be aware of the prices, service quality, tourist selection, uniqueness and innovation of the products offered. Furthermore, Ritchie and Crouch (2003) emphasise close ties between suppliers and marketing intermediaries as well as facilitators. This is because marketing intermediaries serve as the middlemen between suppliers and tourists (the customers). An example of a marketing intermediary is tourism agents. Tourism agents inform tourists about the activities, spaces and activities offered by suppliers at a given tourism destination. This information is usually found in a package, which the tourist will consider in terms of its potential fulfilment and the experiences he, or she is seeking. Subsequently, the tourist will make a decision based on the spaces, activities and products agreed upon by both the tourist and the marketing intermediary.

Among the marketing intermediaries in the tourism industry noted by Ritchie and Crouch (2003) are speciality channellers including tourism firms, tourism corporations, convention and meeting planners, facilitators that serve as assistants in launching and ensuring the smooth running of the tourism industry such as information management (advertising agencies, internet, magazine and newspaper publications), financial sources (credit cards, foreign currency exchange), information enhancement (tourism consultants, diplomats, Internet) and so forth. Additionally, Ritchie and Crouch (2003) stress the role of customers and the public as stakeholders in tourism destination. Customers in this respect refer to tourists themselves while the public refers to local residents, the public sector and the private sector. Undeniably, both the public sector and private sector play distinct roles in tourism destination. This is supported by Pearce (1989) who states that the preparation of services and facilities requires cooperation from all parties in order to satisfy the wants and needs of tourists. Such preparations are usually handled by the private sector while the public sector develops, controls or limits developments.

\subsection{The Role of Public Sector and Private Sector}

Both the public and the private sector play important roles in the development of tourism destination, particularly tourist friendly destination. The public sector is responsible for determining policies and plans as well as setting and enforcing standards relating to facilities, services and other areas. Inskeep (1991) explains that in regard to implementation, the public sector is concerned with several functions such as arranging developments, carrying out rules and regulations on tourism, developing main infrastructure, advancing the appeal of public tourism and 
conducting marketing to promote tourism areas. In the meantime, Gunn (1994) elaborates that the public sector function within the tourism industry is to increase tourist satisfaction, enhance economic and business success, protect existing assets and preserve community integration. The public sector is also more involved in planning, enforcing laws related to tourism destinations and managing the construction of infrastructure as well as public tourism appeal. The public sector also provides space (through infrastructural and superstructural elements, safety, preserved values and costs, accessibility), activities (through elements related to culture and history, special events) and products (through physical traits, services, freedom of choice) which are designed for public use. Examples of public sector-owned spaces, activities and products are national parks, state parks, wildlife, recreation areas, monuments, zoos and sports stadiums (Gunn, 1994).

Similarly, the private sector also plays an important role in the preparation of space, activities and products though it is more focused on profit-oriented development. This is evident from its involvement in space (most private sectors devote attention to developments based on superstructure and suitable locations), activities (developments based on special events, entertainment and group activities) and products (services, hospitality, involvement). In a capitalist economy, the private sector's main functions are geared towards accommodation (hotels, apartments), food and beverages (restaurants, cafes), shopping and entertainment (shopping centres, theme parks, cinemas, MICE) and others. The public sector provides incentives for the investments made by the private sector for tourism destination developments. Inskeep (1991) also states that the public sector occasionally acts as the pioneer in new tourism developments until the private sector is given a boost to invest in the area (tourism destination). Among the spaces, activities and products owned by the private sector are theme parks, shopping centres, resorts, golf courses, theatres, souvenir shops and tourism agencies (Gunn, 1994). Therefore, the formation of tourist friendly destination concept depends on close connections between stakeholders as players in tourism planning and development. The aspects of space, activities and products are greatly emphasised so that tourism destinations, which use tourist friendly destination concept are able to fulfil demands as well as provide tourists with new experiences.

\subsection{The Role of Domestic Tourist}

Since 1960, the tourism industry in Malaysia has veered more towards the international tourist market. According to Weaver and Opperman (2000), the number of domestic tourists has decreased compared to foreign tourists. However, domestic tourists are now beginning to find consideration in tourism plans in a few developing countries (Inskeep, 1991). Pearce (1995) asserts that the scale and number of domestic tourists has even begun to surpass that of foreign tourists while Latham and Edwards (2003) describe the advent of domestic tourists at a given tourism destination as being 10 times more than foreign tourists. Recently, the Malaysian Ministry of Tourism doubled its promotion efforts in order to attract domestic tourists to help stimulate the national tourism industry. The introduction of the new and unique tourism destination concept along with effective promotion strategies has yielded a positive effect on the domestic tourist market. A total of 3,729,245 domestic tourists stayed at hotels in Kuala Lumpur in 2010 (Tourism Malaysia, 2012). Overall, 27,534,771 domestic tourists stayed at hotels all over Malaysia in 2010 (Tourism Malaysia, 2012). Datuk Seri Najib Tun Razak in his capacity as Malaysia’s Prime Minister acknowledged these numbers by stating that the rising costs of living standards has caused Malaysians to select local tourism areas as tourism destinations (Bernama, 2012). He also said that the government would turn Malaysia into a more attractive tourism destination in order to attract more domestic and foreign tourists (Bernama, 2012). The question is who domestic tourists are and what is their role in formation of tourist friendly destination concept?

The WTO defines domestic tourists as people or residents in a country who visit areas within their native country or travel to local destinations that differ from their hometown more than 24 hours or 1 night but not more than 1 year or 12 months for any reason ranging from recreation, leisure, holiday, sport, business, meeting, convention, visiting friends or relatives and so forth (Chadwick, 1994). On the other hand, Smith (1996) describes domestic tourists as residents who travel to destinations within their native country. In a study conducted by the National University of Malaysia (1999) as quoted in Badaruddin (2005), domestic tourists are defined as "anyone living in Malaysia without taking into account his or her citizenship who travels to a place that is at least 40 kilometres (one way) from his or her place of residence, travelling for at least 1 night for any reason aside from following the activities offered at the place". It is important to note here that there is a difference between domestic tourists and domestic visitors. Smith (1996) defines a domestic visitor as someone who travels within his or her own country for any reason for a period lasting less than 24 hours.

Based on the definitions above, domestic tourists clearly have a significant influence on a country's tourism industry aside from tourist friendly destination. Many domestic tourists travel daily and conduct activities such as visiting friends or relatives, using facilities and accommodations (not hotels but second homes, staying at the 
houses of friends or relatives or in tents) (Latham \& Edwards, 2003). This is supported by Chadwick (1987) who notes the diverse activities carried out by domestic tourists (be it primary or secondary activities) such as business trips (conventions, consultations), visits friends or relatives (socialising, eating and drinking together, entertaining at home), having fun (recreation, sightseeing, eating outside) and personal activities (shopping). All of these activities illustrate that domestic tourists make full use of space, activities and products which are important in formation of tourist friendly destination concept.

In a study by Badaruddin (2005), many of the respondents (domestic tourists) travelled for the purpose of taking a holiday or filling their leisure time. The majority of the respondents had pre-planned their trips and were accompanied by friends. The study found that the main factor that persuaded the respondents to visit certain tourism destinations were the attractions offered, abundance of nature, recreational facilities and sufficient leisure time. Aside from that, the study also found that respondents were most likely to do activities such as shopping, sightseeing, eating and drinking at cafes or restaurants, visiting historical sites, exploring the local culture and visiting museums and theme parks. This shows that the respondents enjoyed travelling and experienced a low level of activity-based experiences.

Similar results were found in a study by Forsyte Research (2000) regarding domestic tourists in New Zealand. Based on this study, most of the tourists visited holiday spots in North Island, Canterbury and Otago. Many domestic tourists travel for the purpose of enjoying a holiday of filling their leisure time. They stay with friends or relatives, second homes or hotels for those travelling for business reasons. Most of the profit obtained by stakeholders comes from accommodation, food and beverages, shopping, transportation and recreation. This study illustrates domestic tourists' tendency to keep spending and maximising their use of space, activities and products while conducting tourism activities. Therefore, stakeholders should develop these three elements in formation of tourist friendly destination concept.

\section{Conclusion}

Tourist friendly destination is a concept used by stakeholders to promote tourism destination. This concept is very useful through the positive value in terms of creating a traveling package at reasonable prices, hospitality, the distribution of development such as infrastructure, facilities, accommodation, transportation and finally earned the right distribution to the target group of entrepreneur, such as the local community and the respective stakeholder. Though definitions of stakeholders may vary, in this research it can be concluded that stakeholders are those that play a part in formation of tourist friendly destination concept including tourists (as the demand), industries (private sector, non-profit sector and public sector as the supply) and hosts (comprising the local community and natural surroundings as the recipients of the effects). These stakeholders work together in formation of tourist friendly destination concept through a combination of space, activities and products. In fact, the application of domestic tourists as an indicator of tourist friendly destination development is vital since they are seen as tourists who frequently travel within their native country and are acknowledged by tourism scholars. When travelling, they are definite to maximise their use of space, activities and products offered which form the foundation of tourist friendly destination development. Despite the limited amount of related research in the form of literature, theories, concepts, frameworks and indicators, this preliminary study has identified the stakeholders and their role in formation of tourist friendly destination concept. Although this research has not been tested through empirical research, the points of earlier studies illustrate that there is a relationship between stakeholders (public and private sector) and domestic tourist towards formation of tourist friendly destination concept in connection with the aspects of space, activity and product (refer Figure 1). 


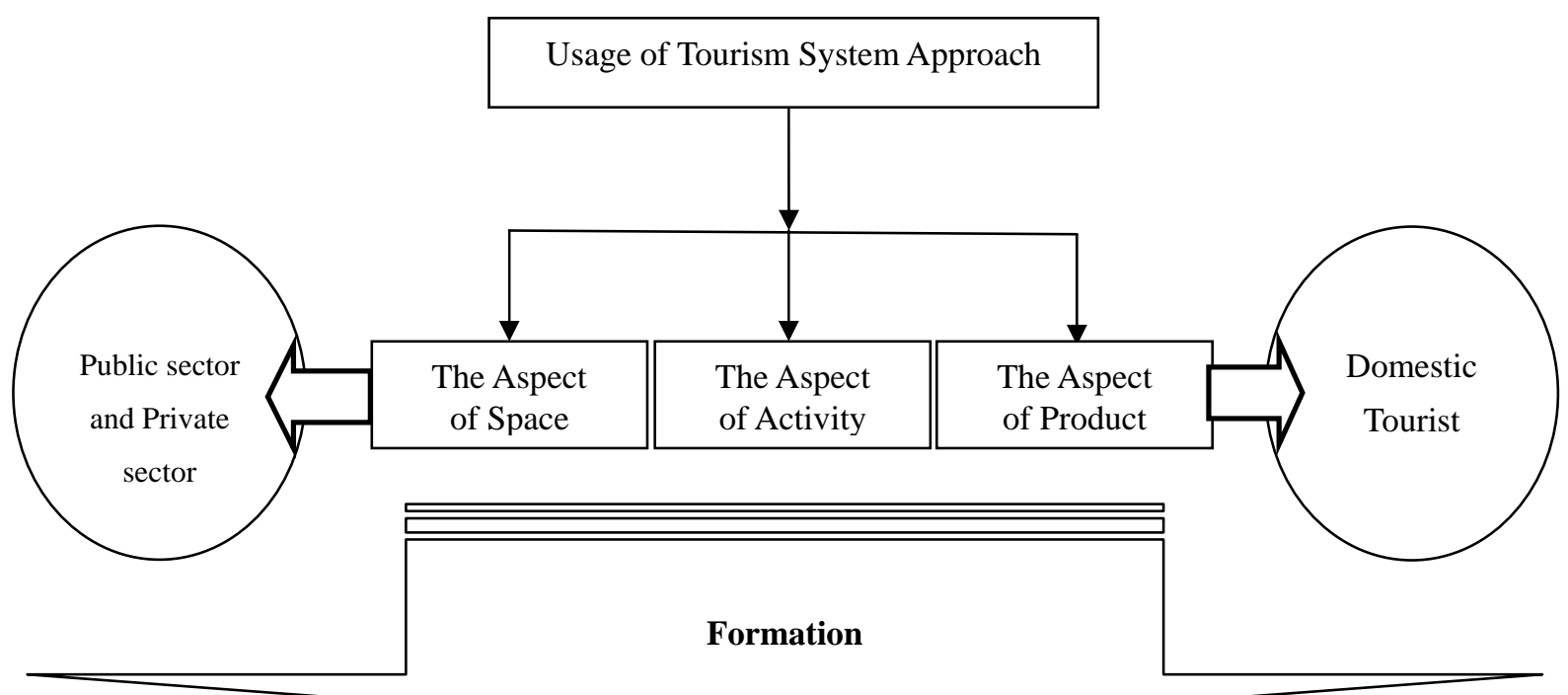

Formation of Tourist Friendly Destination Concept

Figure 1. Conceptual framework for understanding the role of stakeholder in the formation of tourist friendly destination concept

\section{References}

Anuar, A. N. A., Ahmad, H., Jusoh, H., \& Hussain, M. Y. (2012). Understanding the factors influencing formation of tourist friendly destination concept. Journal of Management and Sustainability, 2(1), 106-114. http://dx.doi.org/10.5539/jms.v2n1p106

Badaruddin Mohamed. (2005). The analysis of Malaysian domestic travelers. Proceeding of International Conference on Tourism Development, 373-381.

Bernama. (January 17, 2012). Khazanah istimewa. PM gembira The New York isytihar Melaka destinasi perlu dikunjungi tahun ini. Harian Metro, 12.

Carroll, A. B. (1993). Business and society: Ethics and stakeholder management. SouthWestern: Cincinnati.

Chadwick, R. (1987). A classification of travellers. In Hall, C. M., \& Page, S. J. (Eds.), The geography of tourism and recreation. Environment, place and space (pp. 78). London and New York: Routledge.

Chadwick, R. (1994). Technical definitions of tourism. In Hall, C. M., \& Page, S. J. (Eds.), The geography of tourism and recreation. Environment, place and space (pp. 77). London and New York: Routledge.

Forsyte Research. (2000). New Zealand Domestic Tourism Survey. In Hall, C. M., \& Page, S. J. (Eds.), The geography of tourism and recreation. Environment, place and space (pp. 87). London and New York: Routledge.

Gunn, C. A. (1994). Tourism planning (3rd ed.). London: Taylor and Francis.

Inskeep, E. (1991). Tourism planning. An integrated and sustainable development approach. New York: Von Nostrand Reinhold.

Latham \& Edwards. (2003). Domestic tourism statistics. In Hall, C. M., \& Page, S. J. (Eds.), The geography of tourism and recreation. Environment, place and space (pp. 79). London and New York: Routledge.

Paskaleva-Shapira, K. (2001). Promoting partnership for effective governance of sustainable urban tourism. Working paper INTA International Seminar Tourism in the City-Opportunity Regeneration and Development. SUT Governance.

Pavlovich, K. (2003). The evolution and transformation of a tourism destination network: The Waitomo Caves, New Zealand. Tourism Management, 24, 203-216. http://dx.doi.org/10.1016/S0261-5177(02)00056-0 
Pearce, D. G. (1989). Role of the public and private sector in tourism supply. In Hall, C. M., \& Page, S. J. (Eds.), The geography of tourism and recreation. Environment, place and space (pp. 123). London and New York: Routledge.

Pearce, D. G. (1995). Tourism today: A geographical analysis (2nd ed.). Harlow: Longman

Ritchie, J. R. B., \& Crouch, G. I. (2003). The competitive destination: A sustainable tourism perspective. UK: CABI International. http://dx.doi.org/10.1079/9780851996646.0000

Savage, G. T., Nix, T. W., Whitehead, C. J., \& Blair, J. D. (1991). Strategies for assessing and managing organizational stakeholders. Academy of Management Executive, 5(2), 51-75. Retrieved from http://www.jstor.org/stable/4165008

Smith, S. L. J. (1996). Tourism analysis: A handbook (2nd ed.). London: Longman.

Swarbrooke, J. (1995). The Development and Management of Visitor Attractions. London: Butterworth Heinemann.

Timur, S. (2012). Analyzing urban tourism stakeholder relationship: A network perspective. Retrieved from http://torc.linkbc.ca/torc/downs1/AnalyzingUrbanTourismStakeholderRelationships.pdf

Tourism Malaysia. (2012). Facts \& Figures. Retrieved from http://www.tourism.gov.my/facts_figures/

Weaver, D., \& Opperman, M. (2000). Tourism management. Brisbane: John Wiley \& Sons Australia Ltd. 